\title{
Domestic electricity consumption in Mexican metropolitan areas under climate change scenarios
}

\author{
Adalberto TEJEDA-MARTÍNEZ ${ }^{1 *}$, Irving Rafael MÉNDEZ-PÉREZ2 \\ and Daniela Alejandra CRUZ-PASTRANA ${ }^{3}$ \\ ${ }^{1}$ Grupo de Climatología Aplicada, Universidad Veracruzana. Zona Universitaria s/n, Xalapa, Veracruz, México. C.P. \\ 91020 \\ ${ }^{2}$ Centro de Ciencias de la Tierra, Universidad Veracruzana. Francisco J. Moreno \# 207, Colonia Emiliano Zapata, \\ Xalapa, Veracruz, C.P. 91090. Tel. +52 2288421700 Ext. 12695. \\ ${ }^{3}$ Consultora ambiental, Argentina \#52-73, Colonia Benito Juárez, Xalapa, Veracruz, C.P. 91056. \\ *Corresponding author; atejeda@uv.mx
}

Received: May 10, 2020; accepted: January 7, 2021

\begin{abstract}
RESUMEN
Se estiman las condiciones bioclimáticas humanas ante escenarios de cambio climático para los horizontes temporales en que se alcancen incrementos en la temperatura media global $(\Delta \mathrm{T})$ de $1{ }^{\circ} \mathrm{C}, 1.5^{\circ} \mathrm{C}$ y $2{ }^{\circ} \mathrm{C}$, conforme al artículo $2^{\circ}$ del Acuerdo de París. Se calcularon los consumos eléctricos domésticos para climatización de viviendas en 30 zonas metropolitanas de México que en 2010 tuvieron medio millón o más de habitantes. Se incorporaron estimaciones del efecto de las islas urbanas de calor en las condiciones bioclimáticas. Las necesidades de calefacción disminuirán y en algunos casos desaparecerán, mientras que se incrementarán las de enfriamiento. Los incrementos de consumo para enfriamiento se esperan que sean mayores para Mexicali, Reynosa-Río Bravo, Cancún, Villahermosa y Veracruz, principalmente. Las zonas urbanas que en la segunda década del siglo XXI no o casi no requieren energía para enfriamiento pero que sí lo requerirán a mediados de siglo, son Toluca, Pachuca, Xalapa, San Luis Potosí y Puebla-Tlaxcala.
\end{abstract}

\begin{abstract}
The following estimates analyse human bioclimatic conditions due to climate change in three time horizons, as suggested by Article 2 of the Paris Agreement. Each scenario corresponds to an increase in the global average temperature $(\Delta \mathrm{T})$ of $1{ }^{\circ} \mathrm{C}, 1.5^{\circ} \mathrm{C}$ and $2{ }^{\circ} \mathrm{C}$, respectively. The measurements of residential electricity consumption for air conditioning were made in 30 metropolitan areas of Mexico with at least half a million inhabitants in 2010. Bioclimatic conditions also included estimates of the effects of urban heat islands (UHI). Use of heating will decrease and, in some cases, disappear, while the need for cooling will increase. Electricity consumption due to cooling is expected to increase in Mexicali, Reynosa-Río Bravo (on the border with the United States), Cancún, Villahermosa, and Veracruz (on the shores of the Caribbean Sea and the Gulf of Mexico). Urban areas like Toluca, Pachuca, Xalapa, San Luis Potosí, and Puebla-Tlaxcala used little or no energy for cooling in the second decade of the $21^{\text {st }}$ century but will need to do so halfway through the century.
\end{abstract}

Keywords: Human bioclimate, climate change, energy consumption needs, metropolitan areas. 


\section{Introduction}

Article 2 of the Paris Agreement (United Nations, 2015) suggests "holding the increase in the global average temperature $(\Delta \mathrm{T})$ to $2{ }^{\circ} \mathrm{C}$ and pursuing efforts to limit the temperature increase to $1.5^{\circ} \mathrm{C}$ above pre-industrial levels." Hence, this paper analyses likely human bioclimatic conditions in Mexico for climate change scenarios with time horizons in which global average temperature $(\Delta \mathrm{T})$ reaches $1.5^{\circ} \mathrm{C}$ and $2{ }^{\circ} \mathrm{C}$. The $1{ }^{\circ} \mathrm{C}$ time horizon has been added as an extra tool for decision makers to consider when discussing regulations on residential electricity consumption for air conditioning on the 30 metropolitan areas that had more than half a million inhabitants in 2010 (Table I).

Since the goal of this paper is to estimate the human bioclimate conditions and their effects on residential electricity consumption in Mexico for the rest of the century, warming due to urbanization was added to the global climate change scenarios.

Increase of heat in cities because of urbanization, i.e., urban heat island (UHI), adds up to thermal gain due to climate change. The air in the urban canopy of UHIs is usually warmer than that of the surrounding countryside (Oke, 1987). The combination of these effects will lead to an increase in demand of electricity for air conditioning (AC) to cool indoor areas. Cities that so far can manage without AC will have to add them gradually. The results of Wan et al. (2011) for different climates, especially for Australia (Wang et al., 2010), California (Xu et al., 2012), and Canada (Berardi and Jafarpur, 2020) show that heating will decrease in cities with cold or temperate climates during the summer and, most likely, in all cities during winter.

Previous research in Mexico has estimated changes in human bioclimatic conditions under climate change scenarios. Jáuregui and Tejeda-Martínez (2001) estimated human comfort conditions in Mexico City for a possible doubling of atmospheric $\mathrm{CO}_{2}$ but the UHI effect was not considered. Tejeda-Martínez and Rivas (2003) analysed similarly south-eastern Mexico while Rodríguez et al. (2004) and García and Tejeda-Martínez (2008) analysed the state of Veracruz. García et al. (2010) studied three cities in north-western Mexico. Luyando and Tejeda-Martínez (2010) dealt with the expected bioclimate halfway through the $21^{\text {st }}$ century in five urban regions in Central Mexico, located 2200m above sea level. Luyando (2016) assessed bioclimatic adjustments in Mexico City for the second half of the $21^{\text {st }}$ century as a result of global climate change and urban heating.

Table I. Metropolitan areas (abbreviations in parentheses) with populations of at least half a million in 2010 (INEGI, 2010) and in 2030 (CONAPO, 2006).

\begin{tabular}{lclc}
\hline Metropolitan area & $\begin{array}{c}\text { Population (thousands) } \\
2010 / 2030\end{array}$ & Metropolitan area & $\begin{array}{c}\text { Population (thousands) } \\
2010 / 2030\end{array}$ \\
\hline Valley of Mexico (VMx) & $20117 / 23247$ & Acapulco (Acap)* & $863 / 959$ \\
Guadalajara (Gdl) & $4435 / 5515$ & Tampico (Tamp)* & $859 / 1036$ \\
Monterrey (Mty)* & $4106 / 5362$ & Chihuahua (Chih) & $852 / 1058$ \\
Puebla-Tlaxcala (Pue-Tlax) & $2729 / 3315$ & Morelia (Mor) & $830 / 958$ \\
Toluca (Tol) & $1936 / 2652$ & Saltillo (Salt) & $823 / 1052$ \\
Tijuana (Tij) & $1751 / 2335$ & Veracruz (Ver)* & $812 / 926$ \\
León (León) & $1610 / 1888$ & Villahermosa (Vhsa)* & $755 / 926$ \\
Juárez (Jrez) & $1332 / 1616$ & Reynosa-Río Bravo (Reyn)* & $727 / 960$ \\
La Laguna (Lag)* & $1216 / 1502$ & Tuxtla Gutiérrez (TuxG)* & $684 / 873$ \\
Querétaro (Qro) & $1097 / 1450$ & Cancún (Ccún)* & $677 / 1129$ \\
San Luis Potosí (SLP) & $1040 / 1259$ & Xalapa (Xal) & $666 / 788$ \\
Mérida (Mér)* & $973 / 1246$ & Oaxaca (Oax) & $608 / 703$ \\
Mexicali (Mxli)* & $937 / 1210$ & Celaya (Clya) & $602 / 699$ \\
Aguascalientes (Ags) & $932 / 1188$ & Poza Rica (Prica)* & $514 / 581$ \\
Cuernavaca (Cuer)* & $925 / 1150$ & Pachuca (Pach) & $512 / 664$ \\
\hline
\end{tabular}

* Indicates warm or hot areas. 
Figure IV.2.2 (p. 167) of the $4^{\text {th }}$ National Mexican Memorandum about Climate Change (SEMARNAT-INE, 2010) is a summary of Tejeda-Martínez et al. (2011), which measured the average thermal stress conditions in ten urban areas with more than one million inhabitants in the last decade of the $20^{\text {th }}$ century. It shows estimates of electricity consumption by user in the first decade of the $21^{\text {st }}$ century; projections for 27 cities are presented for time horizons in 2020, 2050, and 2080.

This paper uses the notion of thermal comfort as described by the American Society of Heating, Refrigerating and Air-Conditioning Engineers, which defines it as "[joint] condition[s] of mind which expresses satisfaction with the thermal environment" (Berglund et al., 1997). A common, indirect way to assess thermal sensation is through bioclimatic comfort indices.

Epstein and Moran (2006) and Blazejczyk et al. (2012) concur in classifying the indices into three groups: 1) rational indices, based on the general equation of thermal balance; 2) empirical indices, based on objective and subjective strain; and 3) direct indices, based on direct measurements of environmental variables. The first two groups depend on many variables, some of which require uncommon specific measurements such as radiant temperature of the environment, globe temperature, inner walls' temperatures, and occupants' skin temperatures. The third group is easier to use and apply because it depends on environmental variables. Although these direct indices are relatively old, they are still in use in human bioclimate studies, and perform satisfactorily when compared to sophisticated indices.

Many human bioclimate studies coincide that room temperature, atmospheric humidity, solar radiation, radiation emitted by the surroundings, and wind are the main environmental elements in human thermal sensation (Auliciems and De Dear, 1998). Only indices that depend solely on the temperature and relative humidity are useful enough, since wind and solar radiation can be controlled indoors.

More than 160 indices have been used to assess human bioclimate in the last 100 years (De Freitas and Grigorieva, 2015). The most sophisticated ones simulate the physical and physiological conditions present in the feeling of human comfort. In contrast, the simplest ones use only room temperature and atmospheric humidity as input data. Apparent
Temperature, Effective Temperature, and the $\mathrm{Hu}-$ midex are among those that depend on these last two variables (Anderson et al., 2013; Chirico and Magnavita, 2019; Binarti et al., 2020).

Blazejczyk et al. (2012) found a high coefficient of determination (97\%) between Effective Temperature - a direct index- and the Universal Thermal Comfort Index (UTCI) - a sophisticated index that focuses on physiological adaptation -. According to Auliciems and De Dear (1998), the PMV index and Effective Temperature are the best options to quantify the physiological human response to the thermal environment.

De Freitas and Grigorieva (2017) recently classified and evaluated 165 bioclimatic indices using six evaluation criteria: validity, usability, transparency, sophistication, completeness, and scope under different environmental conditions, assigning up to a maximum score of 30. Effective Temperature stands out with a score of 23, followed by Humidex with 15. Although the Humidex has an average rating, it is found in a number of recent publications on climate change (Oleson et al., 2015; Orosa et al., 2014a; Orosa et al., 2014b; Kum and Celik, 2014; Giannakopoulos et al., 2011), heat waves (Stewart et al., 2017; Lee et al., 2016; Hamdi et al., 2016; Kravchenko et al., 2013; Kershaw and Millward, 2012; Mastrangelo et al., 2007), urban environments (Roshan et al., 2017; Charalampopoulos et al., 2013), and the energy sector (Yildiz et al., 2017; Miller et al., 2017; Marvuglia and Messineo, 2012; Beccalli et al., 2008).

Jáuregui et al. (1997) and Moran and Epstein (2006) showed that if some variables in a complex index are parameterized, its sensitivity and variability are reduced to those of a simple index. Therefore, bioclimatic evaluations based on temperature and humidity variables are still valid.

Hence, this research will use the Effective Temperature index and the Humidex. Preliminary results to those shown in this article appeared in INECC-PNUD (2017a) and SEMARNAT-INECC (2018).

\section{Data and Methods}

\subsection{Data}

Mexico, due to its geographic location, experiences mid-latitude meteorological systems in winter and 
tropical systems in summer. It is also affected by topography and ocean-continent convergence (Mosiño and García, 1974). Thus, we find a great variety of climates that range from hot, with average annual temperatures above $32{ }^{\circ} \mathrm{C}$, to cold, with temperatures below $10^{\circ} \mathrm{C}$, but average annual temperatures in almost $90 \%$ of the country range from $10{ }^{\circ} \mathrm{C}$ to $26^{\circ} \mathrm{C}$. As a whole Mexico has 23\% hot-subhumid, 28\% dry, $21 \%$ very dry, and $21 \%$ temperate-subhumid climates (Magaña, 1999).

The dataset used is known as CLICOM (National Climatological Database), based on the Mexican climatological station network, for the period 1980-2009. The website managed by the Mexican research center CICESE (http://clicom-mex.cicese. $\mathrm{mx}$ ) provides daily maximum and minimum temperature data. Inconsistent records were discarded, for example, those where the daily maximum temperature was lower than the minimum one and vice versa. Stations with less than $80 \%$ of the data were not taken into account. Because of this, calculations for Chihuahua, Reynosa-Río Bravo, and Pachuca used the reanalysis database of Livneh et al. (2015). The spacing of its $1 / 16$ mesh has currently one of the highest resolutions, which provided acceptable values at the required points. The database is also valid for stations with time frames longer than 20 years.

The National Institute of Ecology and Climate Change, and the United Nations Development Programme (INECC-PNUD, 2017b) provided the climate change projections. Output of the GFDL-CM3 and HADGEM2-ES models were used, with radiative forcings RCP4.5 and RCP8.5 for three time horizons that reach increases in the global average temperature of $1.0^{\circ} \mathrm{C}$ (years 2030 to 2048), $1.5^{\circ} \mathrm{C}$ (2041-2066), and $2.0{ }^{\circ} \mathrm{C}$ (2051-2100).

The National Population Council (CONAPO, 2006) provided data on family size in 2010 , population projections for 2030, average family size projections for 2010-2030, population projections for 2030 by district and town to determine future scenarios of population growth, and electricity consumption by user for cooling needs in 2010 with projections for 2030 .

\subsection{Selected bioclimatic index(es)}

The Humidex was developed in Canada in 1965 and modified by Masterton and Richardson (1979). Its algebraic expression is:
$H=T a+\frac{5}{9}(e-10)$

where $\mathrm{Ta}$ is the room temperature in ${ }^{\circ} \mathrm{C}$ and $e$ is the water vapour pressure in $\mathrm{hPa}$.

Effective Temperature (ET) can be expressed as (Missenard, 1933):

$$
E T=T a-0.4(T a-10)(1-f)
$$

Here, the relative humidity $(f)$ is given in decimals.

Only the Humidex was used here since results between using Effective Temperature or Humidex did not vary significantly when converting indices into cooling needs (as energy units, $\mathrm{kW}$-user per year, for example).

\subsection{Hourly hygrothermal data}

Temperature and relative humidity hourly data are required to compare the bioclimatic conditions of 2010 to future ones. Since some files of National Climatological Database (CLICOM database) do not have humidity data, these were obtained by averaging mean monthly extreme temperatures. Comparing base and future scenarios is possible if the same calculation method is used in both.

The average monthly relative humidity was calculated as the ratio of the average monthly vapour pressure $e$ (in $\mathrm{hPa}$ ) and the average monthly saturation vapour pressure $e_{\mathrm{S}}$ (in $\mathrm{hPa}$ ). Atmospheric humidity data are rare in climatological station networks. Hence, $e$ was calculated by the polynomial proposed by Tejeda-Martínez and Rivas (2003), which is dependent of the average monthly minimum temperature $T_{m}$ :

$e=7.5+8.5 \times 10^{-2} T_{m}+3.7 \times 10^{-2} T_{m}^{2}-$

$1.7 \times 10^{-3} T_{m}^{3}+1.9 \times 10^{-4} T_{m}^{4}-5.0 \times 10^{-6} T_{m}^{5}$

$e_{\mathrm{S}}$ was obtained from Adem (1967), using the mean monthly temperature $T$ :

$e_{s}=6.115+0.4291 T+1.4206 \times 10^{-2} T^{2}+$

$3.046 \times 10^{-4} T^{3}+3.2 \times 10^{-6} T^{4}$

The average monthly minimum relative humidity $\left(f_{\min }\right)$ was obtained by combining the monthly mean $e$ with the $e_{\mathrm{s}}$ as a function of the mean maximum temperature $\left(e_{\mathrm{stmax}}\right)$. The average monthly maximum 
relative humidity $\left(f_{\max }\right)$ is derived from the monthly mean $e_{\mathrm{s}}$ as a function of the mean minimum temperature $\left(e_{\text {stmin }}\right)$ :

$f_{\min }=e / e_{\mathrm{stmax}}$ and $f_{\max }=e / e_{\mathrm{stmin}}$

Monthly averages of hourly data were obtained from the equations proposed and used by Tejeda-Martínez (1991), and Tejeda-Martínez and Rivas (2003):

$T_{h o r}=T_{\min }+\left(a t^{b} e^{c t}\right)\left(T_{\max }-T_{\min }\right)$

$f_{\text {hor }}=f_{\min }+\left(1-a t^{b} e^{c t}\right)\left(f_{\max }-f_{\min }\right)$

where $T_{\text {hor }}$ and $f_{\text {hor }}$ are the hourly temperature and relative humidity (in ${ }^{\circ} \mathrm{C}$ and decimals, respectively); $a, b$, and $c$ for latitudes south of the Tropic of Cancer have values of $0.096,2.422$ and -0.339 , respectively. For the tropics and latitudes to the north, values are 0.026, 3.190 and -0.375 (from March to October) and $0.023,3.436$ and -0.421 (from November to February); $t$ is the time of day from sunrise; $T_{\max }, T_{\min }$, $f_{\max }$ and $f_{\min }$ are the average monthly maximum and minimum relative temperatures and humidity for the period 1980-2009 at the selected cities in this study.

Monthly averages or hourly data on temperature, relative humidity, and vapor pressure - which remained unchanged throughout the daytime - were obtained using this method to generate monthly $\mathrm{Hu}$ midex values (Equation 1).

\subsection{Base and future bioclimatic conditions}

For the base period (1980-2009) and climate change scenarios, thermal comfort conditions (monthly, seasonal, and annual) of thirty metropolitan areas (Table I) were analysed. Equations 5 and 6 were substituted in the equations of the selected bioclimatic indices to generate the hygrothermal sensation base period 1980-2009. This sensation is defined as a response to the state of thermoreceptors in a human body and describes how the person feels hygrothermically (Parsons, 2014). It is commonly categorized into cold, cool, slightly cool, neutral, slightly warm, warm, and hot (ASHRAE, 2004). This calculation requires to know the neutral temperature-also called comfort or preferential temperature, or thermopref- erendum, $T_{\mathrm{p}}$ ). For Auliciems (1983), $T_{\mathrm{p}}$ shows the thermal preference of the inhabitants acclimatized to a particular site. The International Union of Physiological Science defined it as "conditions which an individual, organism or a species selects for its ambient environment" (Bligh and Johnson, 1973). There are different models to estimate this value, such as those by García and Tejeda-Martínez (2008), and Martínez et al. (2017). The most-often used equation for tropical latitudes was applied ( $\mathrm{T}$ is the average monthly temperature in ${ }^{\circ} \mathrm{C}$ ):

$$
T_{\mathrm{p}}=0.31 T+17.6
$$

The preferred monthly values for each comfort index were calculated from $T_{\mathrm{p}}$ and $f=0.5$. The comfort interval was established as $T_{\mathrm{p}} \pm 1.5^{\circ} \mathrm{C}$.

INECC-PNUD (2017b) provided the temperature increases due to climate change; these were added to the average monthly hourly values of the base period 1980-2009. This is how we obtained the preferred bioclimatic scenario with climate change. The warming effect due to urbanization, UHI, was also added. According to Jáuregui (1986), the UHI's maximum intensity $\left(H I_{\max }\right)$ in tropical cities, in ${ }^{\circ} \mathrm{C}$, is obtained from population in the urban area $(\mathrm{P})$ as:

$$
H I_{\max }=2 \log _{10} P-8^{0} \mathrm{C}
$$

It is acknowledged that the UHI does not occur in the entire urban area (Tejeda-Martínez et al., 2011); it decreases from the centre towards the periphery and has a daily and an annual variation. Using INEGI's (National Institute of Statistics and Geography) information, Luyando (2016) estimated the UHI's intensity for each basic geographic area. The result, applied here, was one sixth of the maximum intensity calculated with Equation 8. Equation 9 was used in this analysis to estimate the UHI's temperature increase for each of the weather stations at the metropolitan areas studied and each scenario:

$$
H I_{\text {mean }}=\frac{2 \log _{10} P-8^{0} C}{6}
$$

The population forecast $(P)$ as the number of inhabitants in each urban area for the 2030s was used for future projections (Table I, approximately when the $1{ }^{\circ} \mathrm{C}$ mean global warming time horizon is met). 
The value remained unchanged since CONAPO (2006) calculates that the national population will undergo a very slow growth from 2030.

\subsection{Electricity consumption}

Heat degree hours $(H D H)$, corresponding to heating needs, and cold degree hours $(C D H)$, for cooling needs, were calculated as:

$$
\begin{aligned}
& H D H=\sum_{i=1}^{n}\left(\text { hum }_{i}-R_{\text {max }}\right) \text { if } \text { hum }_{i}>R_{\text {max }} \\
& \text { CDH }=\sum_{i=1}^{n}\left(R_{\text {min }}-\text { hum }_{i}\right) \text { if } \text { hum }_{i}>R_{\text {min }}
\end{aligned}
$$

hum $_{\mathrm{i}}$ are the Humidex's average monthly hourly values, $R_{\min }$ is the lower limit (calculated with $f=$ 0.5 and $T_{\mathrm{p}}-1.5^{\circ} \mathrm{C}$ ), and $R_{\max }$ is the upper limit (calculated with $f=0.5$ and $T_{\mathrm{p}}+1.5^{\circ} \mathrm{C}$ ) of the Humidex comfort interval. This useful and simple method is well-known, applied to Istanbul by Durmayaz et al. (2000) and by Assawamartbunlue (2013) in Thailand.

De Buen (2017) estimated annual electricity consumption for comfort in each residential electricity rate $(1,1 \mathrm{~A}, 1 \mathrm{~B}, 1 \mathrm{C}, 1 \mathrm{D}, 1 \mathrm{E}$ or $1 \mathrm{~F})$. These rates are established from the highest average monthly temperatures in three consecutive months over a period of five years, as stated in the Federal Official Gazette (DOF, 2002). Results by De Buen (2017) were used to convert values to energy needs (in $\mathrm{kWh}$, per electric service user). The 30 metropolitan areas were classified according to their electricity rate; an average $C D H$ was taken from those with the same rate. The last column of Table II shows these equivalencies. Since the rate districts 1 and $1 \mathrm{~A}$ had no data on average annual consumption for comfort, they got the same values of rate $1 \mathrm{~B}$.

We established, as a working hypothesis, that consumption will increase not only because of the $C D H$ 's growth due to global and local climate change, but also because of economic factors. AC systems, fans, and refrigerators are increasingly cheaper. De Buen (2017) documented this increase in consumption from 2012 to 2016 . The technology in these devices tends to be more efficient and more AC solutions are passively introduced in housing. It is expected that the increase in AC use due to accessibility will cancel out the decrease due to better technology. Hence, the $\mathrm{CDH}$ equivalence for electricity consumption in the
Table II. Residential electricity rates (DOF, 2002),

\begin{tabular}{|c|c|c|}
\hline $\begin{array}{l}\text { Electricity } \\
\text { rates }\end{array}$ & $\begin{array}{l}\text { Metropolitan areas } \\
\text { (alphabetical order) }\end{array}$ & $\begin{array}{l}\text { Equivalences of } \\
\mathrm{CDH} \text { to } \mathrm{kWh} \text {-user }\end{array}$ \\
\hline 1 & $\begin{array}{l}\text { Aguascalientes, } \\
\text { Celaya, Cuernavaca, } \\
\text { Guadalajara, León, } \\
\text { Morelia, Oaxaca, } \\
\text { Pachuca, Puebla- } \\
\text { Tlaxcala, Querétaro, } \\
\text { Saltillo, San Luis } \\
\text { Potosí, Tijuana, } \\
\text { Toluca, Xalapa and } \\
\text { Valley of Mexico. }\end{array}$ & 0.0055 \\
\hline $1 \mathrm{~B}$ & $\begin{array}{l}\text { Acapulco, Chihuahua, } \\
\text { Poza Rica y Tuxtla } \\
\text { Gutiérrez. }\end{array}$ & 0.0055 \\
\hline $1 \mathrm{C}$ & $\begin{array}{l}\text { Cancún, Juárez, La } \\
\text { Laguna, Mérida, } \\
\text { Monterrey, Tampico } \\
\text { and Veracruz }\end{array}$ & 0.0153 \\
\hline $1 \mathrm{D}$ & Villahermosa & 0.0145 \\
\hline $1 \mathrm{E}$ & Reynosa-Río Bravo & 0.0477 \\
\hline $1 \mathrm{~F}$ & Mexicali & 0.0829 \\
\hline
\end{tabular}
metropolitan areas and equivalences of $C D H$ to $\mathrm{kWh}$-user.

base period will remain the same in the future. Note that the $C D H$ calculations include the acclimatization of the subjects to the thermopreferendum or preferred temperature.

The term "user" in De Buen (2017) refers to electricity meter or the household with an electric service meter. Therefore, to obtain the consumption for cooling per inhabitant, the value gets divided by the average number of people in a household as INEGI registered it for the base period in 2010 (3.19 people per family), and CONAPO's projections for the scenarios $\Delta \mathrm{T}=1.0^{\circ} \mathrm{C}$ (year $2030 ; 3.17$ people per family), $\Delta \mathrm{T}=1.5^{\circ} \mathrm{C}$, and $2.0^{\circ} \mathrm{C}$ (year 2050; 3.01 people per family).

The total consumption of each metropolitan area was evaluated for the base period and for 2030 and 2050 (for example, see Table III). On the other hand, as an energy equivalence regarding the decrease in heating needs ( $\mathrm{HDH}$ ) was not found in the literature, just the reduction percentage was reported (Table IV). 
Table III. Increased electrical consumption (\%) for $\Delta \mathrm{T}=2.0^{\circ} \mathrm{C}$ with respect to the base period (climatology 1979-2012 and population 2010), for warm and hot metropolitan areas.

\begin{tabular}{lccccccc}
\hline & \multicolumn{5}{c}{ Increased electrical consumptions (\%) } \\
\cline { 2 - 4 } \cline { 6 - 8 } Metropolitan area & \multicolumn{3}{c}{ Without UHI } & & \multicolumn{3}{c}{ With UHI } \\
\cline { 2 - 4 } \cline { 6 - 8 } & Yearly & Winter & Summer & & Yearly & Winter & Summer \\
\hline Monterrey & 212 & 336 & 185 & & 247 & 417 & 210 \\
La Laguna & 107 & 85 & 112 & & 132 & 122 & 134 \\
Mérida & 163 & 172 & 156 & & 196 & 210 & 186 \\
Mexicali & 130 & 210 & 107 & & 139 & 234 & 112 \\
Cuernavaca & 447 & $>1000$ & 346 & & 573 & $>1000$ & 432 \\
Acapulco & 84 & 90 & 79 & & 90 & 98 & 83 \\
Tampico & 140 & 218 & 115 & & 159 & 264 & 126 \\
Veracruz & 117 & 139 & 103 & & 132 & 161 & 114 \\
Villahermosa & 130 & 176 & 107 & & 144 & 204 & 114 \\
Reynosa-Río Bravo & 184 & 254 & 165 & & 206 & 298 & 181 \\
Tuxtla Gutiérrez & 192 & 221 & 176 & & 219 & 259 & 197 \\
Cancún & 205 & 235 & 186 & & 226 & 266 & 200 \\
Poza Rica & 136 & 192 & 116 & & 155 & 228 & 130 \\
\hline
\end{tabular}

Table IV. Decrease in heating needs $(\%)$ for $\Delta \mathrm{T}=2.0^{\circ}$ with respect to the base period (climatology 1979-2012 and population 2010).

\begin{tabular}{|c|c|c|c|c|c|c|}
\hline \multirow{2}{*}{ Metropolitan area } & \multicolumn{3}{|c|}{ Without UHI } & \multicolumn{3}{|c|}{ With UHI } \\
\hline & Annual & Winter & Summer & Annual & Winter & Summer \\
\hline Valley of Mexico & 38 & 34 & 44 & 52 & 46 & 61 \\
\hline Guadalajara & 52 & 45 & 66 & 63 & 57 & 76 \\
\hline Monterrey & 47 & 45 & 60 & 59 & 57 & 75 \\
\hline Puebla-Tlaxcala & 31 & 27 & 37 & 40 & 35 & 48 \\
\hline Toluca & 20 & 18 & 23 & 26 & 23 & 30 \\
\hline Tijuana & 37 & 38 & 37 & 46 & 46 & 47 \\
\hline León & 40 & 34 & 51 & 49 & 42 & 63 \\
\hline Juárez & 28 & 25 & 36 & 33 & 30 & 43 \\
\hline La Laguna & 27 & 24 & 43 & 36 & 32 & 54 \\
\hline Querétaro & 35 & 31 & 42 & 44 & 39 & 53 \\
\hline San Luis Potosí & 29 & 26 & 33 & 36 & 32 & 41 \\
\hline Mérida & 67 & 63 & 75 & 79 & 76 & 86 \\
\hline Mexicali & 37 & 35 & 42 & 44 & 41 & 52 \\
\hline Aguascalientes & 35 & 29 & 47 & 43 & 36 & 57 \\
\hline Cuernavaca & 61 & 54 & 76 & 72 & 65 & 88 \\
\hline Acapulco & 0 & 0 & 0 & 0 & 0 & 0 \\
\hline Tampico & 87 & 87 & 100 & 97 & 96 & 100 \\
\hline Chihuahua & 28 & 24 & 38 & 33 & 28 & 44 \\
\hline Morelia & 31 & 28 & 36 & 38 & 34 & 44 \\
\hline Saltillo & 38 & 30 & 64 & 44 & 35 & 74 \\
\hline Veracruz & 100 & 100 & 0 & 100 & 100 & 0 \\
\hline Villahermosa & 0 & 0 & 0 & 0 & 0 & 0 \\
\hline Reynosa-Río Bravo & 49 & 47 & 64 & 57 & 55 & 75 \\
\hline Tuxtla Gutiérrez & 79 & 76 & 99 & 88 & 87 & 100 \\
\hline Cancún & 0 & 0 & 0 & 0 & 0 & 0 \\
\hline Xalapa & 38 & 34 & 44 & 46 & 42 & 54 \\
\hline Oaxaca & 43 & 36 & 54 & 51 & 44 & 65 \\
\hline Celaya & 33 & 32 & 35 & 41 & 38 & 45 \\
\hline Poza Rica & 76 & 75 & 100 & 87 & 86 & 100 \\
\hline Pachuca & 27 & 25 & 29 & 33 & 30 & 36 \\
\hline
\end{tabular}




\section{Results}

Estimated AC needs were calculated from the $\mathrm{Hu}-$ midex, with results from the GFDL-CM3 and HADGEM2-ES models and two radiative forcings (4.5 and $\left.8.5 \mathrm{Wm}^{-2}\right)$. The results shown here correspond to the combination of the Humidex with HADGEM2-ES and a forcing of $8.5 \mathrm{Wm}^{-2}$. This combination was chosen because HADGEM2-ES showed greater sensitivity and the forcing of $8.5 \mathrm{Wm}^{-2}$ for future cooling needs has precautionary value.

The thermal increases by UHI (from Equation 9) range from $1.1{ }^{\circ} \mathrm{C}$, for the metropolitan area of the Valley of Mexico, to $0.6^{\circ} \mathrm{C}$ for Poza Rica. Thus, they are lower than the climate change horizons $\left(1.0^{\circ} \mathrm{C}\right.$, $1.5^{\circ} \mathrm{C}$ and $2.0^{\circ} \mathrm{C}$ ).

Figure 1 shows the annual cooling needs in $C D H$ for all 30 urban centers for the base period, while Figure 2 shows the annual increases in consumption for cooling per inhabitant at horizons $\Delta \mathrm{T}=1.0^{\circ} \mathrm{C}$, $1.5^{\circ} \mathrm{C}$ and $2.0^{\circ} \mathrm{C}$, with and without the UHI. The largest hygrothermal rise is expected in coastal metropolitan areas or near the eastern and southern coasts (Fig. 1). Increases in consumption for cooling are expected to be higher in the metropolitan areas of Mexicali, Reynosa-Río Bravo, Cancún, Villahermosa, Veracruz, Tampico, Monterrey, Mérida, and Ciudad Juárez when converting to energy units per inhabitant (Fig. 2). Note that Ciudad Juárez is located at $1120 \mathrm{~m}$ above sea level, while all others are below $1000 \mathrm{~m}$ above sea level. These are followed by Tuxtla Gutiérrez, Acapulco, and

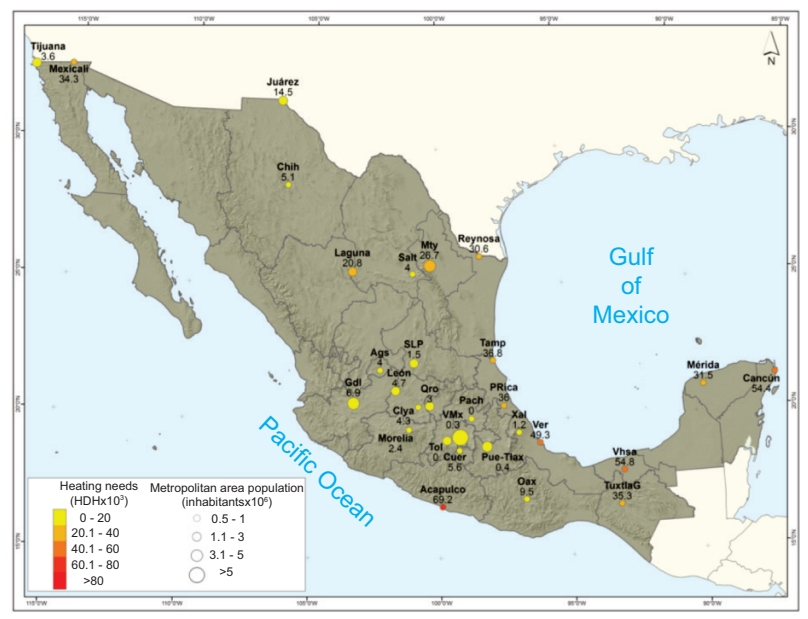

Fig. 1. Annual cooling needs (cold degree hours, $C D H$ ) for base period (climatology 1979-2012 and population 2010).
Poza Rica, also located below 1000m above sea level.

Increases will grow in time, from one $\Delta \mathrm{T}$ horizon to another, and it is expected to be even larger in the presence of UHIs. These increases will be higher from March to August (summer) and will decrease slightly from September to February (winter).

Figure 3, similar to Figure 2 but applied to the entire population in each metropolitan area, shows increases in cooling needs. Monterrey has a larger expansion because of its population. While usage in metropolitan areas in central Mexico will increase minimally, none of them display a reduction in consumption for cooling.

Table III presents the percentage increase in consumption needs for cooling compared to the base period (averages from 1979 to 2012, population from 2010) in warm or semi-warm metropolitan areas for the climate change scenario $\Delta \mathrm{T}=2.0^{\circ} \mathrm{C}$. It is clear that population growth contributes the most to increases in energy consumption.

Figure 4 shows the base period of annual heating needs in Heat Degree Hours $(H D H)$. These values were used to calculate the percentage reductions in Figure 5. As noted above, it was not possible to find energy equivalences because of a lack of conversion from $H D H$ to energy units in the literature.

Acapulco, Villahermosa, and Cancún did not use heating during the base period and, thus, show no reduction in future heating use; similarly for Veracruz during the summer months (March-August). The decline in heating needs increases as time horizons progress $\left(\Delta \mathrm{T}=1.0{ }^{\circ} \mathrm{C}, 1.5^{\circ} \mathrm{C}\right.$ and $\left.2.0^{\circ} \mathrm{C}\right)$.

It is predicted that the largest decrease in heating needs will occur during summer when considering UHI in all metropolitan areas considered. The metropolitan areas of Tampico and Poza Rica show a $100 \%$ decrease in heating needs from time horizon $\Delta \mathrm{T}=1.0^{\circ} \mathrm{C}$ for summers with UHI; Tuxtla Gutiérrez will reach the same decline from horizon $\Delta \mathrm{T}=$ $1.5^{\circ} \mathrm{C}$. This means that the small heating demands during the early morning hours -usually solved by the building's thermal inertia or clothing- will disappear completely in summer. Similar results are found for the metropolitan areas of Valley of Mexico, Guadalajara, Monterrey, León, Mérida, Cuernavaca, Saltillo, Reynosa, and Oaxaca. These areas are expected to have a significant gradual decrease close to or over $60 \%$ in heating use for time horizon $\Delta \mathrm{T}=$ 

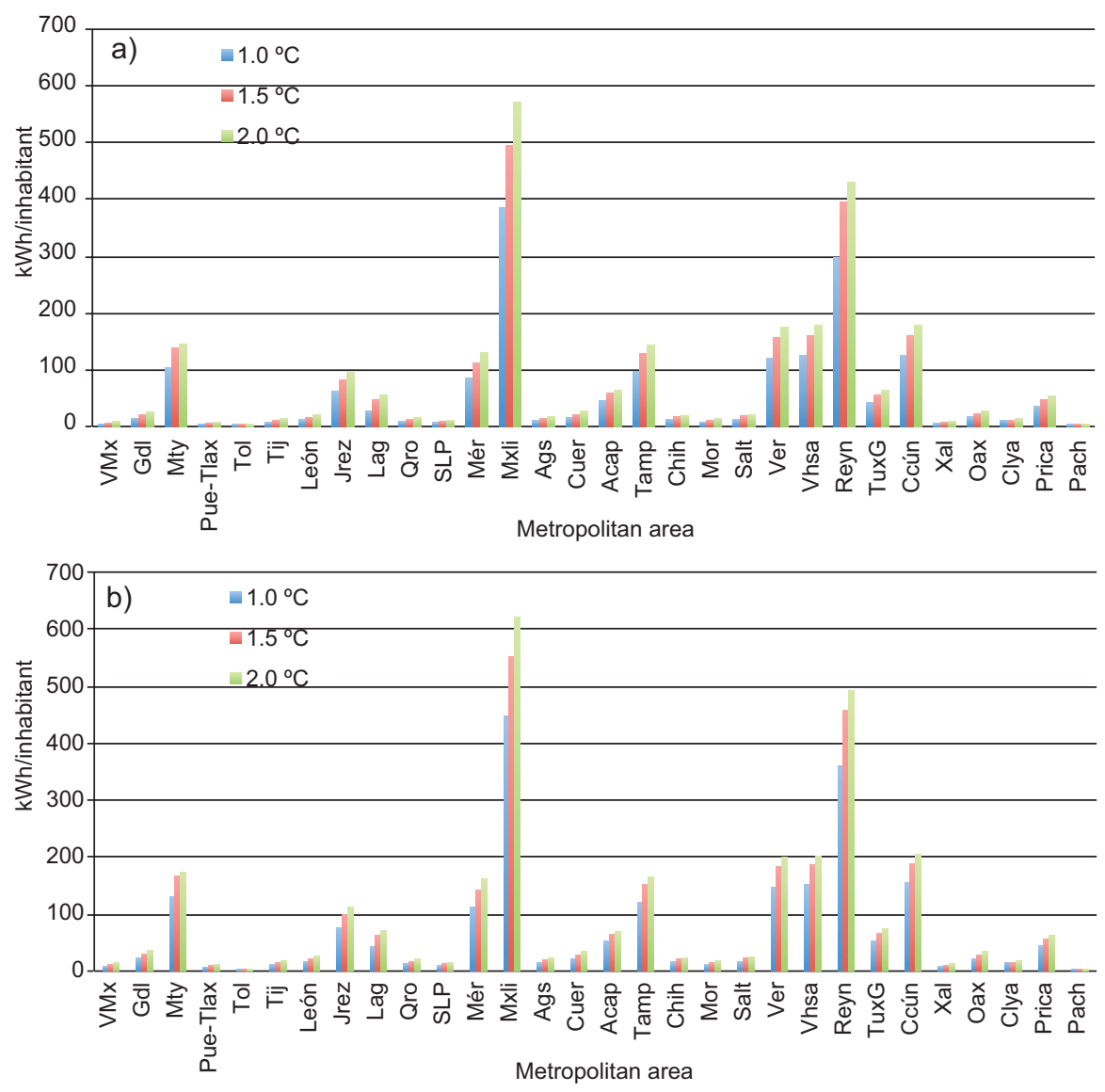

Fig. 2. Annual increases in consumption for cooling ( $\mathrm{kWh} / \mathrm{inh}$ abitant) for time horizons that will reach increases in the average global temperature $(\Delta \mathrm{T})$ of $1{ }^{\circ} \mathrm{C}, 1.5^{\circ} \mathrm{C}$ and $2{ }^{\circ} \mathrm{C}$. a) without UHI, b) with UHI.

$2.0{ }^{\circ} \mathrm{C}$ when the UHI is considered. This reduction means less need for shelter and heating use in cool mornings.

All analysed metropolitan areas show a decrease of at least $15 \%$ for heating needs for winter (results not shown) without considering the UHI; decreases will be less when considering the UHI.

The metropolitan areas that combine both an increase in cooling needs and a decrease in heating needs are Reynosa, Monterrey, Tampico, Mérida, Veracruz, Poza Rica, and Tuxtla Gutiérrez, mainly during summer and considering the UHI. All the analysed metropolitan areas will experience increases in both minimum and maximum temperatures, leading to higher cooling needs and a decrease in heating use.

Table IV shows the decrease in heating needs for $\Delta \mathrm{T}=2.0^{\circ} \mathrm{C}$ compared to the base period. Met- ropolitan areas that in the base period did not have heating needs, show a $0 \%$ decrease. Those with a decrease of $100 \%$ or close to $100 \%$ can gradually abstain from heating.

\section{Discussion}

The methods and results of this study -decreasing heating needs and increasing cooling needs due to climate change- are consistent with those published by Petri and Caldeira (2015) for 25 cities in the United States, Mourshed (2011) for Dhaka and Bangladesh, Christenson et al. (2006) for four cities in Switzerland, and Schoetter et al. (2020) for Toulouse and Dijon in France.

Table V shows the increase intervals in electricity consumption for cooling per inhabitant. This is expected to exceed the $100 \mathrm{kWh}$ per inhabitant in 

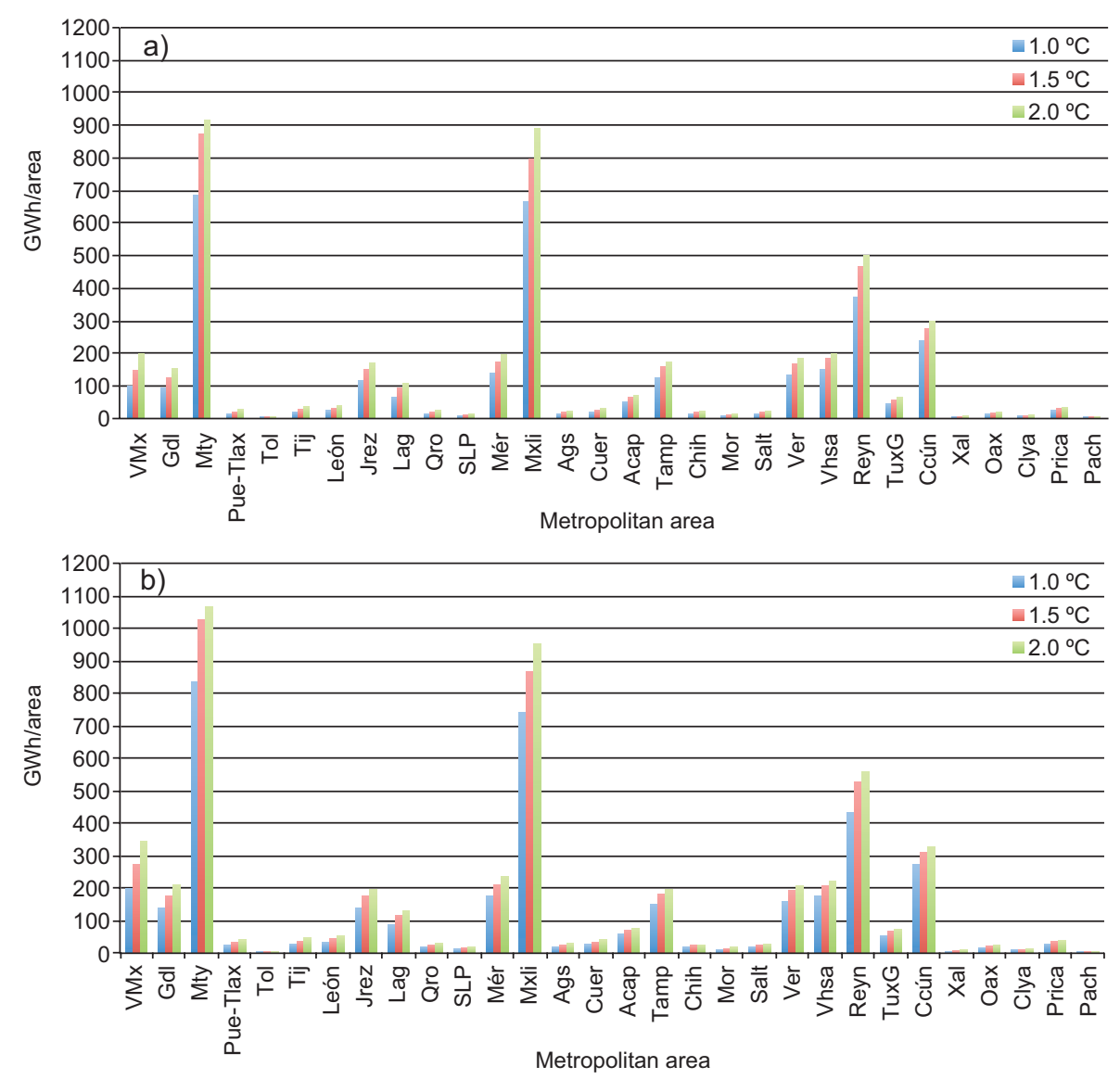

Fig. 3. Annual increases in consumption for cooling (GWh/area) for time horizons that will reach increases in the average global temperature $(\Delta \mathrm{T})$ of $1{ }^{\circ} \mathrm{C}, 1.5^{\circ} \mathrm{C}$ and $2{ }^{\circ} \mathrm{C}$. a) without UHI, b) with UHI.

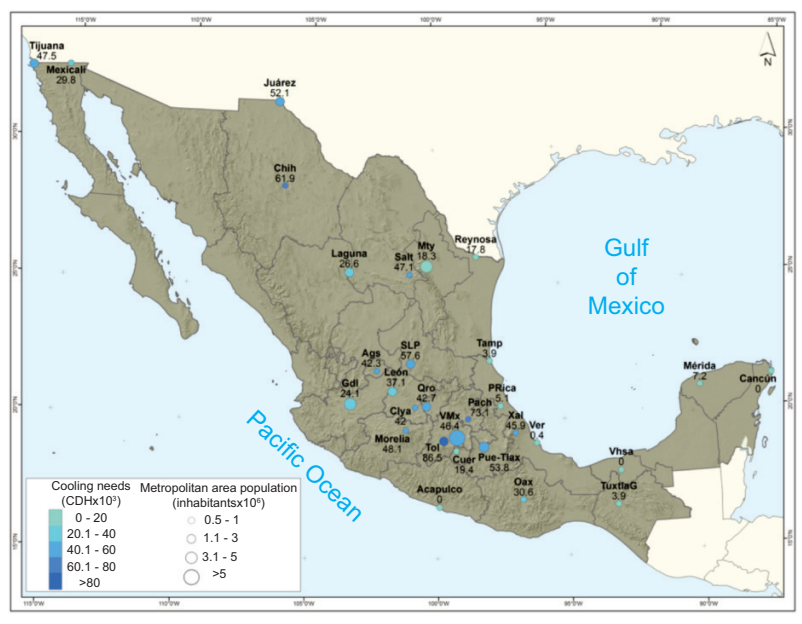

Fig. 4. Annual needs of heating (hot degree hours, HDH) for base period (climatology 1979-2012 and population 2010). metropolitan areas, and ranges from a minimum increase $\left(\Delta \mathrm{T}=1{ }^{\circ} \mathrm{C}\right.$ without $\left.\mathrm{UHI}\right)$ to a maximum one $\left(\Delta \mathrm{T}=2{ }^{\circ} \mathrm{C}\right.$ with $\left.\mathrm{UHI}\right)$. The largest increase will occur in northern Mexico and in urban coastal areas of the Gulf of Mexico and the Caribbean. As previously mentioned, the results of the works cited in the introduction and those of this work correspond in order of magnitude to the percentage of consumption per inhabitant.

Time trends in decadal consumption for four representative areas are shown in Figure 6. As an example, Puebla-Tlaxcala displays a similar behaviour to other temperate zones, such as Toluca, León, Morelia, San Luis Potosí, Aguascalientes, Querétaro, Tijuana, and even the Valley of Mexico. The main difference is the population size in each of them. The trend seen for Monterrey is representative of the pattern seen in 

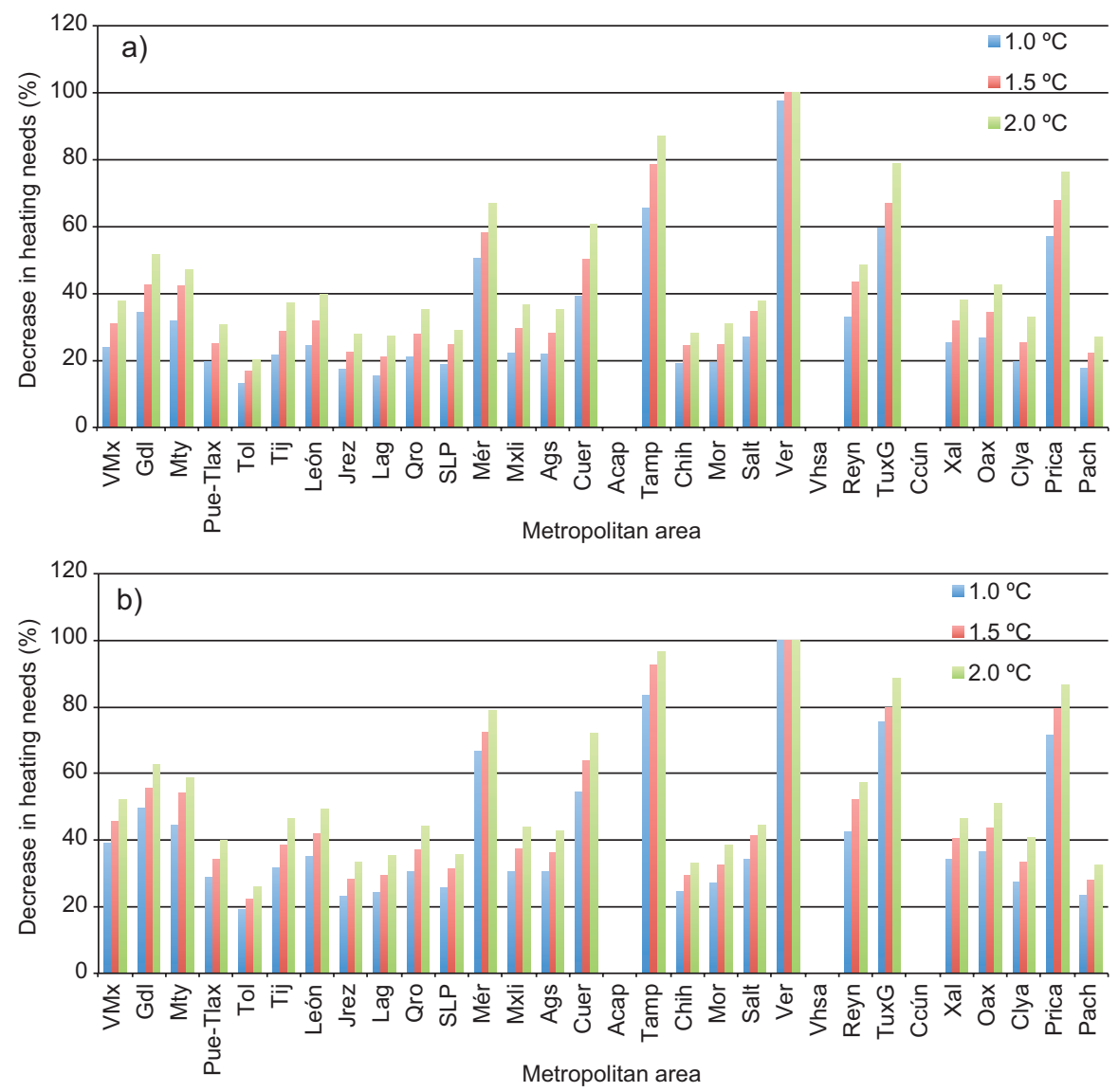

Fig. 5. Decrease in heating needs (\%) for time horizons that will reach increases in the average global temperature $(\Delta \mathrm{T})$ of $1{ }^{\circ} \mathrm{C}, 1.5^{\circ} \mathrm{C}$ and $2{ }^{\circ} \mathrm{C}$. a) without UHI, b) with UHI.

Table V. Metropolitan areas that will increase their cooling needs per inhabitant by more than $100 \mathrm{kWh}$ (see Figure 2).

\begin{tabular}{lcc}
\hline $\begin{array}{l}\text { Metropolitan } \\
\text { area }\end{array}$ & $\begin{array}{c}\Delta \mathrm{T}=1{ }^{\circ} \mathrm{C} \\
\text { without UHI } \\
\text { (kWh/inhabitant) }\end{array}$ & $\begin{array}{c}\Delta \mathrm{T}=2{ }^{\circ} \mathrm{C} \\
\text { with UHI } \\
\text { (kWh/inhabitant) }\end{array}$ \\
\hline Mexicali & 390 & 610 \\
Reynosa & 300 & 500 \\
Villahermosa & 110 & 200 \\
Cancún & 120 & 200 \\
Veracruz & 110 & 200 \\
Monterrey & 100 & 180 \\
Tampico & 100 & 170 \\
Mérida & 90 & 150 \\
Juárez & 60 & 105 \\
\hline
\end{tabular}

other northern warm areas during summer such as Mexicali, Ciudad Juárez, La Laguna, Saltillo, and Reynosa. Note that cooling needs in these northern areas are almost independent of the UHI. This is slightly different in metropolitan areas of the humid tropics like Cancún, Veracruz, Tampico, Acapulco, Tuxtla Gutiérrez, Mérida, and Villahermosa. Three areas are an exception: Celaya, Poza Rica, and Pachuca. CONAPO estimates that population in those areas will decline before mid-century.

Heating needs are certainly expected to decrease under global and local warming scenarios due to urbanization. Results of this study show that the percentage reduction (over 50\%) will be greater in warm places like Mérida, Tampico, Veracruz, Tuxtla Gutiérrez, and Poza Rica. Acapulco and Cancún already used no heating in the base period. Cold areas like Toluca, Pachuca, and Tijuana will decrease use by 15 to $30 \%$, considering the UHI. The decrease in the remaining areas will be between 25 and $60 \%$. However, it is important to note that temperate metropolitan areas (Aguascalientes, Celaya, 

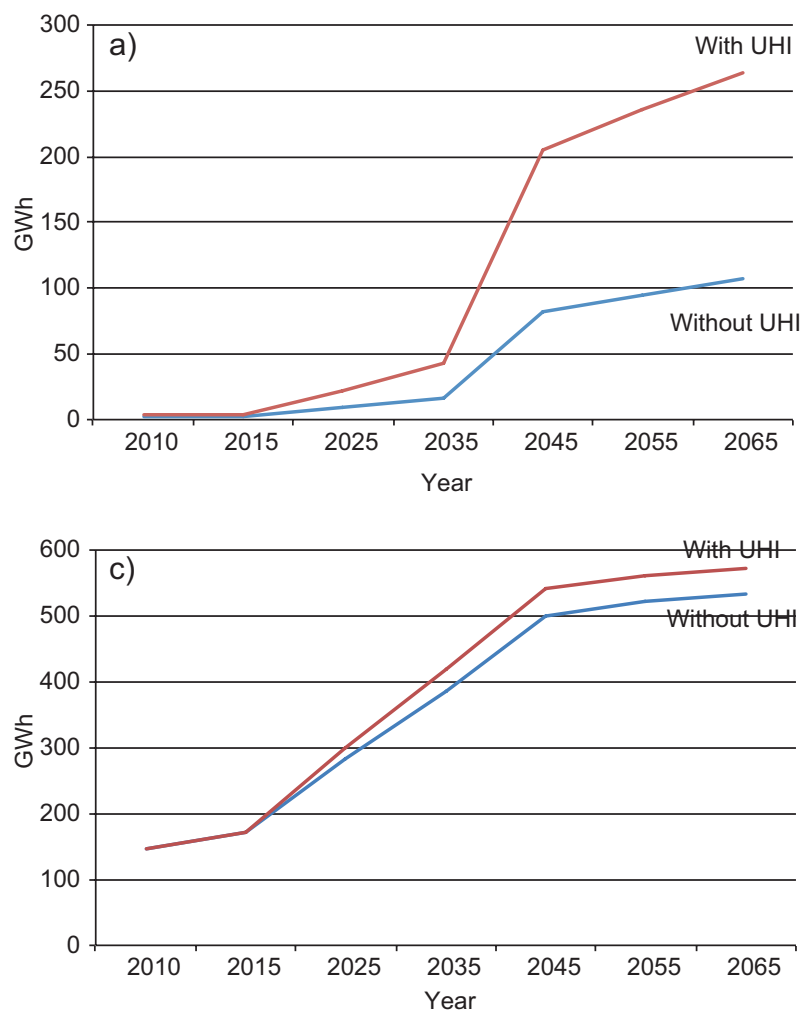
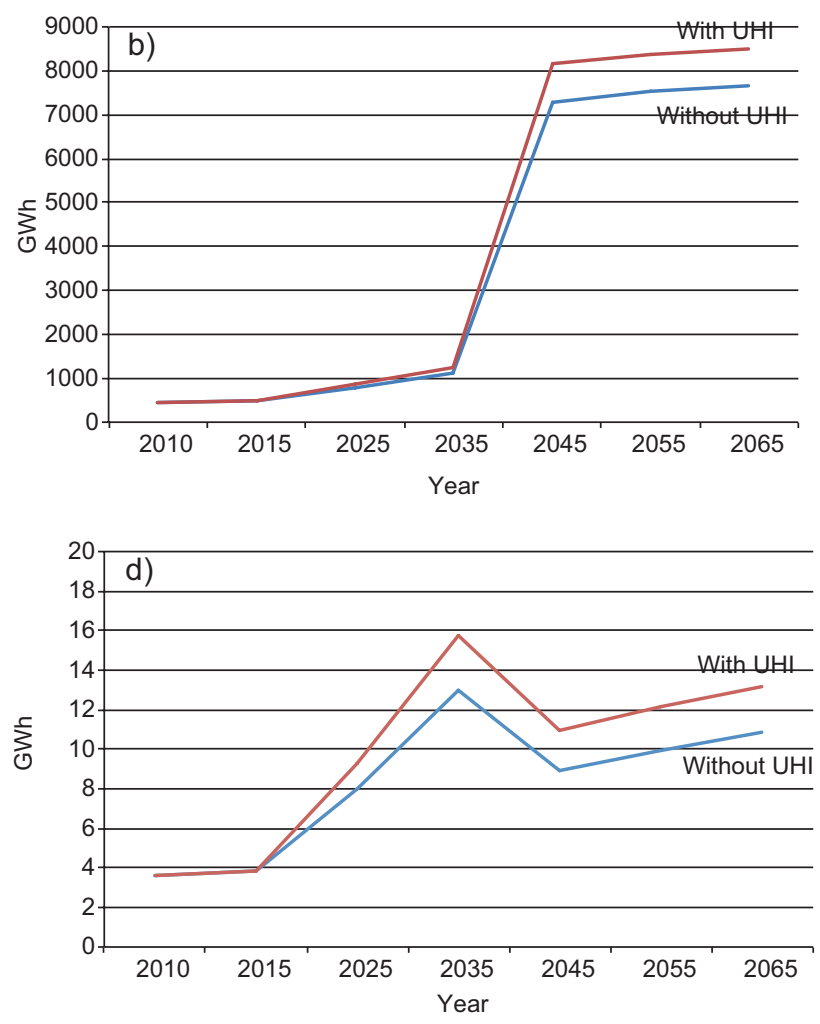

Fig. 6. Four examples of decadal consumption trends: a) Puebla-Tlaxcala, b) Monterrey, c) Cancún, d) Celaya.

Cuernavaca, Guadalajara, León, Morelia, Oaxaca, Pachuca, Puebla-Tlaxcala, Querétaro, Saltillo, San Luis Potosí, Tijuana, Toluca, Xalapa, and Valley of Mexico) experience extreme minimum temperatures below $5^{\circ} \mathrm{C}$ in the base period, and it is very likely that cold waves will continue to affect them in the future.

\section{Recommendations}

Some regions of the country have already experienced a shortage of electricity due to excessive demand derived from AC use (Loret de Mola, 2017; Arias, 2019; ADN, 2019). This study shows that the situation will worsen in the future. Moreover, cold urban areas, like Toluca, Pachuca, and Tijuana, have also experienced heat waves increasing AC demand. Recommendations resulting from this analysis point towards a need to reduce AC energy consumption through measures inside buildings and in urban environments, as well as to develop awareness campaigns.

There is a sustainable building framework in Mexico for residential areas (CONAVI, 2010) but it is not mandatory. There are also two official Mexican standards issued with the purpose of reducing energy consumption from AC in buildings: NOM-018-ENER-2011 (Thermal Insulation for Buildings. Features and Test Methods), and NOM-020-ENER- 2011 (Energy Efficiency in Construction. Building Enclosures for Residential Use). Although both are mandatory, their compliance is not truly monitored. There are also some voluntary Mexican technical standards: NMX-AA-164-SCF1-2013 (Sustainable Building: Minimum Environmental Criteria and Requirements), NMX-AA-171-SCFI-2014 (Requirements and Specifications of Environmental Performance in Lodging Facilities), and NMX-AA-SCFI-157-2012 (Sustainability Requirements and Specifications for Site Selection, Design, Construction, Operation, and Abandonment of Tourist Property Development Sites in Coastal Areas of the Yucatán Peninsula).

Local government needs to embrace these regulations and, together with state and federal governments, promote, monitor, and implement those regulations. It is also recommended that energy providers (particularly, 
the Federal Electricity Commission, CFE) get involved in monitoring compliancy with NOM-018 and NOM-020 official standards, ensuring that all new and renovated properties comply with these regulations.

Important measures have been implemented in the last decade. For example, the National Workers Housing Fund (INFONAVIT) started the Green Mortgage Program, which grants an additional credit for eco-technologies that save water, electricity, and gas. These technologies include solar heaters, thermal insulation, energy saving lighting, etc. The National Housing Council launched "This is Your Home", a program that links subsidies to a series of criteria that guarantee property's sustainability.

The government of Mexico City (formerly the Federal District) issued a Sustainable Building Certification Program in 2008. It established a standard to reward residential and commercial buildings with tax or financial incentives. However, most of these buildings have been built by large commercial developers and have been certified by international standards, namely LEED (Leadership in Energy and Environmental Design) rather than by individuals. LEED and similar labels, do not correspond with Mexico's socioeconomic, cultural, and technological aspects and cannot be applied nationwide.

It is recommended that each metropolitan area incorporates new regulatory codes to current urban development regulations. Construction licenses should include compliance with energy efficiency and sustainable building measures. For example, a building's thermal load or an energy simulation could be listed as prerequisite to obtain licenses for building construction or remodelling. This is similar to the Building Energy Certificate required for developers in the European Union. It is, therefore, paramount that municipal authorities, research centers, professional associations, and industrial chambers of construction and housing work together towards achieving the same goal.

UHI intensity tend to increase morbidity and mortality in children and the elderly. In Mexico City, for example, children between the ages of 0 and 14 suffer acute diarrhoea as a consequence of the UHI and climate change (Vargas and Magaña, 2020). In Barcelona, Spain, from 1992 to 2015, elderly men and women were the most vulnerable groups (Ignole, et al, 2020).
Mitigation of UHIs requires a higher density of green areas. The aforementioned standard NMXAA-164-SCF1-2013 (for Sustainable Building) establishes that the percentage of free areas must be $10 \%$ larger than the minimum value established by local regulation, without parking areas. Moreover, these common areas for users and visitors should allow water infiltration.

Ventilation should also be promoted. Rows of tall buildings on the seashore often disturb the local sea breeze regimes in coastal cities. New real estate developments should therefore consider fresh wind corridors to enhance ventilation of residential areas. However, in humid climates, adding more humidity to the environment can increase the intensity or duration of hygrothermal discomfort, which could lead to increased installation of AC systems. Particularly in urban environments where promoting ventilation may be difficult, mitigating the UHI's intensity would not only lead to energy savings, but would also ease the strength of heat waves and promote better quality of life.

\section{Acknowledgements}

This study was sponsored by the National Institute for Ecology and Climate Change (INECC) and the UN Development Programme. Óscar Sánchez-Meneses, Elisa Tejeda-Zacarías, Maryam Nava-Assad and Pablo Hernández-Ávila provided computational support. Noé González Flores and Adrián ÁlvarezPérez improved tables and figures.

\section{References}

Adem J. 1967. Parametrization of atmospheric humidity using cloudiness and temperature. Monthly Weather Review 95: 83-88. https://doi.org/10.1175/1520-049 3(1967)095<0083:POAHUC $>2.3 . C O ; 2$

ADN. 2019. Apagones en BCS son por sobrecarga por altas temperaturas. Available at https://www.adn40. $\mathrm{mx} /$ noticia/mexico/notas/2019-07-30-17-28/apagonesen-bcs-son-por-sobrecarga-por-altas-temperaturas (accessed 06/30/2019)

Anderson GB, Bell ML Peng RD. 2013. Methods to calculate the heat index as an exposure metric in environmental health research. Environmental Health Perspectives 121: 1111-1119. https://doi.org/10.1289/ ehp. 1206273 
Arias, A. 2019. Arrecia el calor y también los apagones en Matamoros. HoyTamaulipas. Available at https:// www.hoytamaulipas.net/notas/382854/Arrecia-el-calor-y-tambien-los-apagones-en-Matamoros $\% \mathrm{C} 2 \% \mathrm{~A} 0$. html (accessed 05/21/2019)

ASHRAE. 2004. Thermal environmental conditions for human occupancy. Standard 55-2004. American Society of Heating, Refrigerating and Air-Conditioning Engineers, Atlanta, USA.

Assawamartbunlue, K. 2013. An investigation of cooling and heating degree-hours in Thailand, Journal of Clean Energy Technologies 1: 87-90. https://doi.org/10.7763/ JOCET.2013.V1.21

Auliciems A. 1983. Psycho-physiological criteria for global zones of building design. In: Overdieck O. Muller J, Lieth H, eds. Proceedings 9th International Society of Biometeorology Conference, Part 2, Biometeorology 8. Swets and Zetlinger, Lisse, 69-86.

Auliciems A, De Dear R. 1998. Thermal adaptation and variable indoor climate control. In: Auliciems A, ed. Advances in Bioclimatology 5. Human bioclimatology. Berlin: Springer-Verlag, 61-68.

Beccalli M, Cellura M, Lo Brano V, Marvuglia A. 2008. Short-term prediction of household electricity consumption: assessing weather sensitivity in a Mediterranean area. Renewable and Sustainable Energy Reviews 12: 2040-2065. https://doi.org/10.1016/j. rser.2007.04.010

Berardi U, Jafarpur P. 2020. Assessing the impact of climate change on building heating and cooling energy demand in Canada. Renewable and Sustainable Energy Review 121: 109681. https://doi.org/10.1016/j. rser.2019.109681

Berglund L, Breckenridge J, Yoshida J. 1997. Chapter 8. Thermal Comfort. In: Parsons R, ASHRAE Fundamentals Handbook. Atlanta: ASHRAE, 8.1-8.28.

Binarti F, Koerniawan MD, Triyadi S, Utami SS, Matzarakis A. 2020. A review of outdoor thermal indices and neutral ranges for hot-humid regions. Urban Climate 31: 100531. https://doi.org/10.1016/j. uclim.2019.100531

Blazejczyk K, Epstein Y, Jendritzky G, Staiger H, Tinz B. 2012. Comparison of UTCI to selected thermal indices. International Journal of Biometeorology 56: 515-535. https://doi.org/10.1007/s00484-011-0453-2

Bligh J, Johnson KG. 1973. Glossary of terms for thermal physiology. Journal of Applied Physiology 35: 941961. https://doi.org/10.1152/jappl.1973.35.6.941
Charalampopoulos I, Tsiros I, Chronopoulou A. Matzarakis A. 2013. Analysis of thermal bioclimate in various urban configurations in Athens, Greece. Urban Ecosystems 16: 217-233. https://doi.org/10.1007/s11252012-0252-5

Chirico P, Magnavita N. 2019. New and old indices for evaluation heat stress in an indoor environment: some considerations. International Journal of Environmental Research Public Health 16: 1444. https://doi. org/10.3390/ijerph16081444

Christenson M, Manz H, Gyalistras D. 2006. Climate warming impact on degree-days and building energy demand in Switzerland. Energy Conversion and Management 47: 671-686. https://doi.org/10.1016/j. enconman.2005.06.009

CONAPO. 2006. Proyecciones de la población de México 2005-2050. Distrito Federal: Consejo Nacional de Población.

CONAVI. 2010. Código de edificación de vivienda. Distrito Federal: Comisión Nacional de Vivienda.

De Buen O. 2017. Análisis de los consumos unitarios y estacionales por usuarios en tarifas residenciales entre 2012 y 2016 para identificar evolución de la demanda por aire acondicionado. Ciudad de México: SENER-CONUEE

De Freitas C, Grigorieva E. 2015. A comprehensive catalogue and classification of human thermal climate indices. International Journal of Biometeorology 59: 109-120. https://doi.org/10.1007/s00484-0140819-3

De Freitas C, Grigorieva E. 2017. A comparison and appraisal of a comprehensive range of human thermal climate indices. International Journal of Biometeorology, 61: 487-512. https://doi.org/10.1007/s00484016-1228-6

DOF (Diario Oficial de la Federación, 2002). Acuerdo que autoriza el ajuste, modificación y reestructuración a las tarifas para suministro y venta de energía eléctrica y reduce el subsidio a las tarifas domésticas. Poder Ejecutivo / Secretaría de Hacienda y Crédito Público. Available at http://dof.gob.mx/nota_to_imagen_fs.php?cod_diario $=28749$ \&pagina $=2 \&$ seccion $=1$ (accessed 05/21/2019)

Durmayaz A, Kodioglu M, Sen Z. 2000. An application of the degree-hours method to estimate the residential heating energy requirement and fuel consumption in Istanbul. Energy 25: 1245-1256. https://doi.org/10.1016/ S0360-5442(00)00040-2 
Epstein Y, Moran D. 2006. Thermal comfort and the stress indices. Industrial Health 44: 388-398. https://doi. org/10.2486/indhealth.44.388

García G, Tejeda-Martínez A. 2008. Consumos eléctricos para climatización de viviendas ante escenarios de cambio climático en el estado de Veracruz, México. PALAPA 3: 39-45. https://www.redalyc.org/ pdf/948/94814774006.pdf

García O, Santillán N, Tejeda-Martínez A, Ojeda S, Bojórquez G. 2010. Escenarios comparativos del confort térmico en tres ciudades del noroeste de México bajo condiciones actuales y de cambio climático. En: Fernández F, Galán E, Cañada R, eds. Clima, salud y ecosistemas. Madrid: Asociación Española de Climatología, 515-526.

Giannakopoulos C, Kostopoulou E, Varotsos KV, Tziotziou K, Plitharas A. 2011. An Integrated assessment of climate change impacts for Greece in the near future. Regional Environmental Change 11: 829-843. https:// doi.org/10.1007/s10113-011-0219-8

Hamdi R, Duchene F, Berckmans J, Delcloo A, Vanpoucke C, Termonia P. 2016. Evolution of urban heat wave intensity for the Brussels Capital Region in the ARPEGE-Climat A1B scenario. Urban Climate 17: 176-195. https://doi.org/10.1016/j.uclim.2016.08.001

Ignole V, Marí-Dell'Olmo M, Deluca A, Quijal M, Borrel C, Rodríguez-Sanz M, Achebak H, Lauwaet D, Gilabert J, Murage P, Hajat S, Basagaña X, Ballester J. 2020. Spatial variability of heat-related mortality in Barcelona from 1992-2015: A case crossover study design. International Journal Environmental Research Public Health 17: 2553. https://doi.org/10.3390/ ijerph17072553

INECC-PNUD. 2017a. Estudio de análisis de las condiciones del bioclima humano en ciudades mexicanas ante escenarios de cambio climático para los horizontes temporales en los que se alcance un incremento en la temperatura media global de $1{ }^{\circ} \mathrm{C}, 1.5^{\circ} \mathrm{C}$ y $2{ }^{\circ} \mathrm{C}$. Proyecto 85488 Sexta Comunicación Nacional de México ante la Convención Marco de las Naciones Unidas sobre el Cambio Climático. Estudio elaborado por Adalberto Tejeda Martínez, Ciudad de México: 47.

INECC-PNUD. 2017b. Estimación de rangos de incertidumbre en las fechas para alcanzar los valores de incremento en la temperatura promedio global 1.0, 1.5 y $2.0^{\circ} \mathrm{C}$ y las implicaciones para la República Mexicana como producto de la Sexta Comunicación Nacional de México ante la Convención Marco de las
Naciones Unidas sobre el Cambio Climático. Estudio elaborado por Oscar Casimiro Sánchez Meneses, Ciudad de México: 29.

INEGI. 2010. Censo de Población y Vivienda 2010. Distrito Federal: Instituto Nacional de Estadística y Geografía.

Jáuregui E. 1986. Tropical urban climate of Mexico City. In: Oke T. Proceedings WHO Technical Conference on Urban Climatology and its Applications with Special Regard to Tropical Areas. Geneva: WMO, 63-86.

Jáuregui E, Cervantes J, Tejeda-Martínez A. 1997. Bioclimatic conditions in Mexico City -an assessment. International Journal of Biometeorology 40: 166-177. https://doi.org/10.1007/s004840050038

Jáuregui E, Tejeda-Martínez A. 2001. A scenario of human thermal comfort in Mexico City for $2 \mathrm{CO}_{2}$ conditions. Atmósfera 14: 125-138.

Kershaw SE, Millward AA. 2012. A spatio-temporal index for heat vulnerability assessment. Environmental Monitoring and Assessment 184: 7329-7342. https:// doi.org/10.1007/s10661-011-2502-z

Kravchenko J, Abernethy AP, Fawzy M, Lyerly HK. 2013. Minimization of heatwave morbidity and mortality. American Journal of Preventive Medicine 44: 274-282. https://doi.org/10.1016/j.amepre.2012.11.015

Kum G, Celik MA. 2014. Impacts of global climate change on the Mediterranean Region: Adana as a case study. Procedia-Social and Behavioral Sciences 120: 600-608. https://doi.org/10.1016/j.sbspro.2014.02.140

Lee JS, Byun HR, Kim DW. 2016. Development of accumulated heat stress index based on time-weighted function. Theoretical and Applied Climatology 124: 541-554. https://doi.org/10.1007/s00704-015-1434-x Livneh B, Bohn TJ, Pierce DW, Muñoz-Arriola F, Nijssen B, Vose R, Cayan DR, Brekke L. 2015. A spatially comprehensive, hydrometeorological data set for Mexico, the U.S., and Southern Canada 1950-2013. Scientific Data 2, 150042. https://doi.org/10.1038/sdata.2015.42 Loret de Mola, C. 2017. Apagón en Península de Yucatán, por sobrecarga. Available at https://www.radioformula. com.mx/noticias/mexico/20170523/apagon-en-peninsula-de-yucatan-por-sobrecarga-cfe-con-loret-de-mola/ (accessed 05/22/2019)

Luyando E, Tejeda-Martínez A. 2010. Escenarios de bioclima humano en la megalópolis del centro de México ante cambio climático. En: Fernández F, Galán E, Cañada R, eds. Clima, ciudad y ecosistemas. Madrid: Asociación Española de Climatología, 527-536. 
Luyando E. 2016. Efectos de las temperaturas y precipitaciones extremas en el bioclima humano de la Zona Metropolitana de la Ciudad de México por cambio climático local y global. Tesis de Doctorado en Geografía, Universidad Nacional Autónoma de México.

Magaña V. (ed.). 1999. Los impactos de El Niño en México. SEP-Conacyt.

Martínez KE, Alcántara A, Bojórquez G, Gómez LG. 2017. Preferencia y sensación térmica en viviendas naturalmente ventiladas en Manzanillo, Colima. Cuadernos de Arquitectura 7: 87-97.

Marvuglia A, Messineo A. 2012. Using recurrent artificial neural networks to forecast household electricity consumption. Energy Procedia 14:45-55. https://doi. org/10.1016/j.egypro.2011.12.895

Masterton JM, Richardson FA. 1979. Humidex, a method of quantifying human discomfort due to excessive heat and humidity. Atmospheric Environment Service, Environment Canada.

Mastrangelo G, Fedeli U, Visentin C, Milan G, Fadda E, Spolaore P. 2007. Pattern and determinants of hospitalization during heat waves: an ecologic study. BMC Public Health 7: 200. https://doi.org/10.1186/14712458-7-200

Miller R, Golab L, Rosenberg C. 2017. Modelling weather effects for impact analysis of residential time-of-use electricity pricing. Energy Policy 105: 534-546. https:// doi.org/10.1016/j.enpol.2017.03.015

Missenard F. 1933. Température effective d'une atmosphère généralisation température résultante $\mathrm{d}$ >un milieu. In Missenard F, Étude physiologique et technique de la ventilation. Leon: 131-185.

Moran DS, Epstein Y. 2006. Evaluation of the Environmental Stress Index (ESI) for hot/dry and hot/web climates. Industrial Health 44: 399-403. https://doi. org/10.2486/indhealth.44.399

Mosiño PA, García E. 1974. The climate of Mexico. In: Bryson RA, Hare FK, eds. World survey of climatology, Vol. II, Climates of North America, London: Elsevier, 345-404.

Mourshed M. 2011. The impact of the projected changes in temperature on heating and cooling requirements in buildings in Dhaka, Bangladesh. Applied Energy 88: 3737-3746. https://doi.org/10.1016/j.apenergy.2011.05.024

Oke TR. 1987. Boundary Layer Climates. London: Routledge.
Oleson KW, Monaghan A, Wilhelmi O, Barlage M, Brunsell N, Feddema J, Hu L, Steinhoff DF. 2015. Interactions between urbanization, heat stress and climate change. Climatic Change. 129: 525-541. https://doi. org/10.1007/s10584-013-0936-8

Orosa JA, Costa AM, Rodríguez-Fernández A, Roshan G. 2014a. Effect of climate change on outdoor thermal comfort in humid climates. Journal of Environmental Health Science and Engineering 12: 46. https://doi. org/10.1186/2052-336X-12-46

Orosa JA, Roshan G, Negahban S. 2014b. Climate change effect on outdoor ambiences in Iranian cities. Environmental Monitoring and Assessment 186: 1889-1898. https://doi.org/10.1007/s10661-013-3502-y

Parsons K. 2014. Human thermal environments. The effects of hot, moderate, and cold environments on human health, comfort, and performance. Boca Raton: CRC Press.

Petri Y, Caldeira K. 2015. Impacts of global warming on residential heating and cooling degree-days in the United States. Scientific Reports 5: 12427. https://doi. org/10.1038/srep12427

Rodríguez L, Tejeda-Martínez A, Utrera G. 2004. Demanda eléctrica para enfriamiento residencial en el estado de Veracruz ante la duplicación de $\mathrm{CO} 2$ en la atmósfera. En Rodríguez M. Estudios de Arquitectura Bioclimática. Anuario 2004. Distrito Federal: UNAM-LIMUSA, 325-338.

Roshan GR, Farrokhzad M, Attia S. 2017. Defining thermal comfort boundaries for heating and cooling demand estimation in Iran's urban settlements. Building and Environment 121: 168-189. https://doi.org/10.1016/j. buildenv.2017.05.023

Schoetter R, Hidalgo J, Jougla R, Masson V, Rega M, Pergaud J. 2020. A statistical-dynamical downscaling for the urban heat island and building energy consumption - Analysis of its uncertainties. Journal of Applied Meteorology and Climatology 59: 859-883. https:// doi.org/10.1175/JAMC-D-19-0182.1

SEMARNAT-INE. 2010. IV. Programas que comprenden medidas de adaptación al cambio climático (impactos, vulnerabilidad y adaptación). En SEMARNAT-INE, México. Cuarta Comunicación Nacional ante la Convención Marco de las Naciones Unidas sobre Cambio Climático. Distrito Federal: Solar, Servicios Editoriales, 119-174.

SEMARNAT-INECC. 2018. México: Sexta comunicación nacional y segundo informe bienal de actualización 
ante la Convención Marco de las Naciones Unidas sobre el Cambio Climático. Ciudad de México: INECC-SEMARNAT, 478-482.

Stewart RE, Betancourt D, Davies JB, Harford D, Klein Y, Lannigan R, Mortsch L, O'Connell E, Tang K, Whitfield PH. 2017. A multi-perspective examination of heat waves affecting Metro Vancouver: now into the future. Natural Hazards 87: 791-815. https://doi. org/10.1007/s11069-017-2793-7

Tejeda-Martínez A. 1991. An exponential model of the curve of mean monthly hourly air temperature. Atmósfera 4: 139-144.

Tejeda-Martínez A, Rivas D. 2003. El bioclima humano en urbes del sur de México para condiciones de duplicación de $\mathrm{CO} 2$ atmosférico. Investigaciones Geográficas 51: 37-52. https://doi.org/10.14350/rig.30413

Tejeda-Martínez A, Luyando E, Jáuregui E. 2011. Average conditions of thermal stress in Mexican cities with more than one million inhabitants in the face of climatic change. Atmósfera 24: 15-30.

United Nations. 2015. Paris Agreement. Available at https://unfccc.int/sites/default/files/english_paris_agreement.pdf (accessed 03/07/2019)
Vargas N, Magaña V. 2020. Warm spells and climate risk to human health in the Mexico City Metropolitan Area. Weather, Climate, and Society 12:351-365. https://doi. org/10.1175/WCAS-D-19-0096.1

Wan KKW, Li DHW, Liu D, Lam JC. 2011. Future trends of building heating and cooling loads and energy consumption in different climates. Building and Environment 46: 223-234. https://doi.org/10.1016/j. buildenv.2010.07.016

Wang X, Chen D, Ren Z. 2010. Assessment of climate change impact on residential building heating and cooling energy requirement in Australia. Building and Environment 45: 1663-1682. https://doi.org/10.1016/j. buildenv.2010.01.022

Xu P, Huang YJ, Miller N, Schlege N, Shen P. 2012. Impacts of climate change on building heating and cooling energy patterns in California. Energy 44: 792-804. https://doi.org/10.1016/j.energy.2012.05.013

Yildiz B, Bilbao JI, Sproul AB. 2017. A review and analysis of regression and machine learning models on commercial building electricity load forecasting. Renewable and Sustainable Energy Reviews 73: 11041122. https://doi.org/10.1016/j.rser.2017.02.023 